\title{
Neovisnost Albanije 1912. na temelju njemačke diplomatske dokumentacije
}

\author{
ISMIJE BESHIRI \\ Priština, Kosovo \\ beshirii@hotmail.com
}

\begin{abstract}
Događaji koji su prethodili neovisnosti Albanije podrobno su dokumentirani u njemačkom diplomatskom arhivu. Njemački diplomati iz regije, u Istanbulu, Ateni, Sofiji, Solunu, Skopju i Cetinju, kao i oni u glavnim gradovima velesila, u Londonu, Rimu, Sankt Peterburgu i Beču, izvještavali su Berlin o događanjima u europskom dijelu Osmanskoga Carstva. Cilj je ovoga rada proučiti spomenute dokumente i učiniti ih dostupnima široj javnosti i novim generacijama povjesničara. Bibliografija njemačkoga Ministarstva vanjskih poslova Auswaertiges Amt, Politisches Archiv Findbuch, Auswaertiges Amt 1867-1920 katalogizira sve dokumente o Albaniji pod vladavinom Carigrada do 1914. jer je njemačko veleposlanstvo u Carigradu do 1914. bilo zaduženo za Albaniju. Te je godine Njemačka prvi put otvorila veleposlanstvo u Tirani te se od tada dokumenti za Albaniju katalogiziraju zasebno. Iz arhivirane dokumentacije vidljivo je da je Njemačka bila vrlo zainteresirana za događanja u Albaniji te da je aktivno podržavala albansku neovisnost, odnosno uspostavljanje albanske države.
\end{abstract}

Ključne riječi: Albanija; Osmansko Carstvo; Balkan; otpor; mladoturci; neovisnost; njemačka diplomatska dokumentacija

Neovisnost Albanije uslijedila je zahvaljujući albanskom otporu od 1909. do 1912., ali i balkanskim ratovima, koji su doveli do poraza Turaka i pada Osmanskoga Carstva u Europi.

Albanci su prvi podržali mladoturke, pokret koji je zapravo nastao na Balkanu, u nadi da će tako uživati više decentralizacije i nacionalnih prava. Međutim, kada su došli na vlast, mladoturci su se okrenuli u suprotnom pravcu. Pod utjecajem njemačkoga jakobinizma, smatrali su da bi se različite etničke skupine trebale osjećati više kao Osmanlije, a manje kao Arapi, Albanci, Kurdi, Armenci itd. To se nije svidjelo različitim etničkim skupinama u Carstvu, uključujući Albance.

Albanci su svake godine podizali ustanke, na koje su mladoturci odgovarali svim sredstvima represivne moći. To je rezultiralo jačanjem centralne države, 
zabranom uporabe albanskoga jezika i jačanjem turske administracije na čelu s mladoturcima. ${ }^{1}$ Da bi spriječili moguće ustanke, počeli su razoružavati lokalno stanovništvo, i to u dva navrata, 1910. i 1911. godine. To je još više pogoršalo situaciju, posebice s albanske strane. Albanci su bili nacija koja je, prema starim pravilima Carstva, oduvijek uživala pravo nošenja oružja.

Ustanci 1910. i 1911. godine

Taj novi osmanizam smetao je Albancima, koji su u veljači 1910. podignuli ustanak na Kosovu. Prema zapisima njemačkoga vojnog atašea u Istanbulu, do nepredviđenoga razvoja situacije dolazi kada je, nakon ubojstva guvernera (muhtesarif) u Peći, Osmansko Carstvo odlučilo premjestiti postrojbe u Skopje i na Kosovo. ${ }^{2}$

U albanskoj historiografiji općenito se iznosi da je Njemačka imala prilično nedefinirana stajališta, pa čak i da nije bila naklonjena Albaniji i njezinoj neovisnosti. Ta je ideja potekla od povjesničara iz razdoblja komunizma, a pripisivali su ju kancelaru Ottu von Bismarcku, koji je vodio Berlinski kongres 1878. i koji je, prema navodima tih povjesničara, o Albaniji govorio samo kao o zemljopisnom području. ${ }^{3}$ Postoje tvrdnje u albanskoj historiografiji da je Njemačka doista podržavala Austro-Ugarsku u njezinoj politici prema Balkanu i da nije imala nikakav izravni interes ni politiku prema njemu. ${ }^{4}$ Ta je hipoteza djelomično istinita jer je Njemačka u to vrijeme bila više zainteresirana za globalno geoekonomsko širenje nego za balkansku politiku. Međutim, stvaranje balkanskih saveza i povećanje interesa Rusije na Balkanu doveli su do razvoja njemačke politike o Balkanu. Njemačka je počela promatrati Balkan iz perspektive ekonomske dobiti, ocijenivši ga mogućim profitabilnim tržištem budućnosti i mostom prema Bliskom istoku. Ali, iznad svega, Njemačka je morala podržati svoju saveznicu Austro-Ugarsku, čiji su interesi bili izravno ugroženi ruskim širenjem prema Balkanu i teritorijalnim pretenzijama novih monarhija Balkana prema albanskim i makedonskim teritorijima.

Njemački diplomati redovito su izvještavali o događanjima u Istanbulu i regiji, a isto je činio i njemački vojni ataše u Istanbulu.

U jednom njemačkom izvješću kaže se sljedeće: „Na području Prištine albansko pleme Hasi, koje ne poštuje ustavni režim, okupilo je oko 10000 ljudi u Prištini, koji su se dobro rasporedili s namjerom da napadnu grad."

1 IVETIC, Luftrat Ballkanike, 51.

2 AAPA, Findbuch, A 6418 (Militaerbericht No 269, Constantinopel, den 10 April 1910); Historia e Shqipërisë, sv II i III, 439.

3 Historia e Shqipërisë, sv. II, 214.

4 RIZAJ, Shqipëria e Sipërme, 197.

AAPA, Findbuch, A 6680 (Salonik, den 6 April 1910). 
Uslijed tih tenzija Njemačka je zajedno s Austro-Ugarskom upozorila Osmansko Carstvo neka bolje postupa prema Albancima da se spriječi porast nezadovoljstva. Ako bi se tenzije nastavile, ustanak bi se proširio, što bi imalo negativne posljedice za cijelo Carstvo, od čega bi profitirale samo Rusija i Srbija jer bi ojačali panslavenski elementi na Balkanu. ${ }^{6} \mathrm{U}$ izvjesnim razdobljima neki su njemački i austrougarski diplomati vjerovali da iza toga ustanka stoji Rusija. No takve su sumnje opovrgnute te je Austro-Ugarska počela mijenjati svoje mišljenje o ustanku, ${ }^{7}$ vjerujući da će ih Osmanlije optužiti za potporu ustanku, što se na kraju i dogodilo. ${ }^{8}$

Njemački i austrougarski diplomati vjerovali su da je jedan od elemenata koji su doveli do ustanka posjet srpskoga kralja Istanbulu u travnju 1910. jer su Albanci sumnjali da Srbi protiv njih s Osmanlijama pripremaju tajni sporazum. ${ }^{9}$ Prema njemačkoj dokumentaciji, vlada u Istanbulu optuživala je parlamentarce albanske nacionalnosti (Ismail Qemal, Ferid Pasha, Nexhip Bey Draga i Hasan Bey Prishtina) za organizaciju ustanka i prijetila da će ih kazniti za pobunu protiv Carstva. ${ }^{10}$ Parlamentarci su tražili da se ti problemi razmotre u parlamentu i da se uspostavi istražna komisija koja će otići u Albaniju, ali to im nije odobreno. Međutim, veliki vezir ipak se tajno susreo s njima. Dogovora nije bilo jer je njihov zahtjev za istražnu komisiju odbijen. ${ }^{11}$

U isto su se vrijeme slavenski narodi i Grci ozbiljno pribojavali da će AustroUgarska Monarhija otvoreno podržati Albance. Stoga su u zapadnom javnom mišljenju i medijima počeli širiti glasine protiv Albanaca i njihove borbe. $U$ Bugarskoj je čak bilo pokušaja da se to pitanje poveže s položajem Bugara na tim područjima, uz tvrdnje da je položaj njihovih bugarskih sunarodnjaka ugrožen, a Bugarska je prijetila da će se umiješati ako budu ugroženi njezini interesi. ${ }^{12}$

Osmansko Carstvo rasporedilo je tijekom travnja i svibnja brojne postrojbe u Skopje, na sjever Albanije i na Kosovo. Prema nekim izvješćima, u svibnju je u taj predio raspoređeno 30000 ljudi pod vodstvom Šefketa Turgut-paše, ${ }^{13}$ ali i albanski ustanici okupili su 20000 ljudi. Međutim, do svibnja su osmanske postrojbe zauzele Kačaničku klisuru i prugu do Skopja. ${ }^{14} \mathrm{U}$ međuvremenu su vođene brojne bitke, poput one u Ljumi, Prizrenu, Peći, a najpoznatija je bitka kod Štimlja. ${ }^{15}$ Osmanske postrojbe nisu spremne dočekale te borbe, a

\footnotetext{
6 AAPA, Findbuch, A 6207 (Wien, den 7 April 1910), Telegram from Wien den 14 April 1910; RIZAJ, Shqipëria e Sipërme, 200.

Isto.

AAPA, Findbuch, A 6416 (Pera, den 10 April 1910).

Isto.

10 AAPA, Findbuch, A 6680 (Selaniki, den 14 April 1910).

1 AAPA, Findbuch, A 7537 (Pera, den 1 Mai 1910).

2 AAPA, Findbuch, A 7772 (Sofia, den 2 Mai 1910).

3 AAPA, Findbuch, A 8251 (Pera, den 10 Mai 1910); Historia e Shqipërisë, sv. II, 440.

4 AAPA, Findbuch, A 7897 (Salonik, den 4 Mai 1910).

5 AAPA, Findbuch, A 8123 (Selonik, den 8 Mai 1910); Historia e Shqipërisë, sv. II, 440.
} 
diplomatski pritisak, posebno Austro-Ugarske, da Osmansko Carstvo sklopi dogovor s Albancima postajao je sve veći. ${ }^{16}$

Već je krajem svibnja Osmansko Carstvo u Skopje poslalo svojega ministra obrane Mahmuda Ševket-pašu ${ }^{17}$ da bi pregovarao s pobunjenicima, koji su zapravo imali dva zahtjeva: 1) smanjenje poreza na prijašnje stope i 2) povlačenje svih postrojbi s albanskih teritorija. Vjeruje se da je za prvi zahtjev ministar mogao naći rješenje, ali drugi je zahtjev bio nešto o čemu Osmanlije nisu bili spremni pregovarati. ${ }^{18} \mathrm{U}$ međuvremenu je izbio još jedan sukob $\mathrm{u}$ Osmanskom Carstvu, na Kreti, koji će odvući međunarodnu pozornost od albanskoga sukoba i Osmanlijama ostaviti slobodne ruke u Albaniji. ${ }^{19}$

U njemačkoj arhivi sačuvano je i anonimno pismo prijatelja njemačkoga veleposlanika u Carigradu u kojem mu priopćava da mora što prije napustiti Tursku, ali ga i upozorava da „njemački kralj mora hitno intervenirati da bi zaustavio krvoproliće, ali i zaštitio turske interese. U svakom slučaju, on je jedini kralj kojemu Albanci vjeruju”. ${ }^{20}$

Ustanak 1910., koji je okončan porazom Albanaca, pokazao je da su dobili nešto pomoći u naoružanju od Italije, pa su se počeli organizirati u razne udruge. Međutim, na stotine izbjeglica uputilo se nakon ustanka u Crnu Goru, ${ }^{21}$ što je njoj dalo posebnu ulogu. Njemačka dokumentacija pokazuje da je razoružavanje raznih naoružanih skupina na Balkanu uspješno završeno do kraja rujna 1910. godine. ${ }^{22}$ U studenom 1910. Osmansko Carstvo ukinulo je izvanredno stanje u Makedoniji, ali na zahtjev kosovskoga valije isto nije učinjeno i za Kosovo, što pokazuje koliko je situacija na Kosovu još uvijek bila ozbiljna. ${ }^{23}$

Godine 1911. i promjena vremena bila je dovoljna da te udruge i izbjeglice ponovno pokrenu ustanak. Tako je u veljači počeo ustanak u Debru i brdima oko Skadra. ${ }^{24}$ Njemački diplomati u Berlinu već su tijekom veljače izvještavali o velikim tenzijama u Skopju, ali i o zategnutim odnosima između Osmanskoga Carstva i Italije ${ }^{25}$ uslijed sukoba koji je počeo iste godine i završio talijanskim zaposjedanjem Tripolija i Bengazija. U Srbiji je sve upućivalo na to da se Srbi pripremaju za rat. ${ }^{26} \mathrm{U}$ ožujku 1911. Albanci su zauzeli gradić Tuzi ${ }^{27} \mathrm{u}$ blizini crnogorske granice. To je uzrokovalo zabrinutost u Crnoj Gori, koja

${ }_{16}$ AAPA, Findbuch, A. S. 622 (Wien, den 10 Mai 1910).

${ }_{17}$ RIZAJ, Shqipëria e Sipërme, 204; Historia e Shqipërisë, sv. II, 444.

18 AAPA, Findbuch, A 8509 (Selanik, den 13 Mai 1910).

19 AAPA, Findbuch, A 8492 (Therapia, den13Mai 1910).

20 AAPA, Findbuch, den 8 Mai 1910.

${ }^{21}$ AAPA, Findbuch, Cetinje, den 15 Juli 1910.

AAPA, Findbuch, A 15006.

3 AAPA, Findbuch, A 19999 (Salonik, den 29 November 1910).

4 BARTEL, Albanien: Vom Mittelalter bis zur Gegenwart. Regensburg , 1995, 125.

AAPA, Findbuch, A 2172 (Belgrad, den 4 Februar 1911).

AAPA, Findbuch, A 2381 (Belgrad, den 9 Februar 1911).

7 AAPA, Findbuch, A 5150 (Cetinje, den 27 Maerz 1911). 
je memorandumom zatražila intervenciju velesila za zaustavljanje sukoba, uz jamstva da će povratnici biti razoružani i da neće predstavljati prijetnju Osmanskom Carstvu. ${ }^{28}$ Kako je situacija eskalirala, Crna Gora našla se pod pritiskom većega broja izbjeglica te je poslala drugi memorandum velesilama. Međutim, velesile su odlučile poslati samo usmeni odgovor te odbile intervenirati. Poslije su upozorile crnogorskoga kralja Nikolu neka se ne miješa na strani albanskih ustanika niti im daje naoružanje ili bilo koju vrstu pomoći. On je u prisutnosti predstavnika velesila u Cetinju objavio zabranu miješanja $\mathrm{u}$ to pitanje, ${ }^{29}$ iznoseći, međutim, da Crna Gora ne može spriječiti sve koji se žele uključiti u pobunu jer katolička plemena u Crnoj Gori pripadaju istom albanskom plemenu kao i izbjeglice. ${ }^{30}$

I Albanci su kasnije iste godine predstavili memorandum velesilama. U takozvanoj Crvenoj knjizi tražili su: 1) da Albanija dobije status pokrajine; 2) da albanske škole financira država; 3) da albanski ročnici u mirnodopskom razdoblju vojni rok služe u Albaniji. ${ }^{31}$

Godine 1911. odnosi među velesilama, dijelom i zbog Albanije, bili su vrlo zategnuti, a albansko pitanje bilo je jedan od izvora neslaganja. Tijekom razgovora s ruskim veleposlanikom u Beču austrijski ministar vanjskih poslova Alois Lexa von Aehrenthal rekao mu je: „Ako uistinu želimo mir, moramo ostaviti balkanske narode da izgore u plamenu požara koji su sami potpalili."32 Međutim, ta nemarna politika Austrije drastično se mijenja tijekom ljetnih mjeseci, kada austrijski tisaki javno mišljenje počinju kritički promatrati vladinu politiku, optužujući Austro-Ugarsku da zanemaruje dužnost koju ima prema albanskim katolicima -prema kulturnom protektoratu (Kultusprotektorat) iz 1857., Austro-Ugarska je bila zaštitnik albanskih katolika.

Uoči posjeta sultana Kosovu situacija na albanskim teritorijima bila je uzavrela. Zabilježene su pobune u Mirditi ${ }^{33}$, Skadru, Tirani, Kruji, Kavaji. ${ }^{34}$ U jednom izvješću iz Soluna kaže se da su Malisori ${ }^{35}$ proglasili nezavisnost od Osmanskoga Carstva. ${ }^{36}$ Još jedna važna prekretnica 1911. bio je sultanov posjet Kosovu. Sultan je na Kosovo polje stigao preko Soluna da bi posjetio grob svojega prapradjeda Murata I. Polagane su nade u to da će sultan Mehmed V. osobno vidjeti situaciju i reagirati na zatečene probleme. Prema njemačkim zapisima, sultan je imao i 10.000 lira da ih podijeli sirotinji i prošlogodišnjim izbjeglicama u Crnoj Gori. ${ }^{37}$

${ }^{28}$ AAPA, Findbuch, A 3373 (Cetinje, den 25 Februar 1911).

29 AAPA, Findbuch, A 6610 (Cetinje, den 23April 1911).

30 AAPA, Findbuch, A 6677 (Cetinje, den 25 April 1911).

31 AAPA, Findbuch, A 7013 (Salonik, den 29 April 1911).

32 AAPA, Findbuch, A 8361 (Wien, den 26 Mai 1911).

AAPA, Findbuch, A 8895 (Cetinje, den 4 Juni 1911).

${ }^{34}$ AAPA, Findbuch, A 8935 (Cetinje, den 5 Juni 1911).

${ }^{35}$ Gorštaci u današnjoj sjevernoj Albaniji.

${ }^{6}$ AAPA, Findbuch, A 9115 (Salonik, den 5 Juni 1911).

${ }^{7}$ AAPA, Findbuch, A 9118 (Constantinopel, den 6 Juni 1911). 
Kao i prethodne godine, Albanci su prikupljali naoružanje, posebice iz Italije, ali i drugih država. U jednom izvješću iz Trsta stoji da je u Albaniju preko Trsta poslano 20000 pušaka, koje su došle iz Hamburga, a financirao ih je Balkanski klub u Londonu. ${ }^{38}$

U cijeloj toj kaotičnoj situaciji važnu je ulogu odigrao crnogorski kralj, osobito nakon dolaska mnoštva albanskih izbjeglica u Crnu Goru. Istovremeno je igrao ulogu žrtve i pobjednika. Uspješno je pokazao važnost Crne Gore u tom balkanskom kaosu, a to mu je pomoglo da stekne financijsku korist od Rusije, Austro-Ugarske i Italije. Jedino je Austro-Ugarska uvidjela ulogu kralja, kao i to da nastoji izvući korist iz teške situacije i proširiti svoj teritorij na albansku zemlju. ${ }^{39}$

Međutim, kraj ljeta označio je i kraj albanskoga otpora. Prema nekim njemačkim izvorima, Osmanlije su optuživali Austro-Ugarsku za davanje potpore albanskom ustanku iz vlastitih interesa. Austrija se ponovno našla pod oštrom kritikom domaćega tiska i javnosti zato što nije ispunila svoju dužnost prema Albancima u skladu s kulturnim protektoratom. ${ }^{40}$ Nakon kritika na račun austrijske vlade, iznesenih posebno u tisku, Austrija je pojačala svoje napore prema Osmanskom Carstvu u korist albanskoga pitanja. No, to je zakompliciralo odnose unutar Trojnoga saveza. Uslijed pritiska Austrije i drugih velesila, Osmansko Carstvo ponudilo je oprost svim pobunjenicima i slobodan prolaz izbjeglicama na povratku u svoje krajeve. Međutim, Albanci su u novom memorandumu tražili ujedinjenje svih četiriju albanskih pokrajina (vilajeta) u jedinstvenu pokrajinu. ${ }^{41}$ Još jedan memorandum upućen je Velikoj Britaniji, s istim zahtjevima u pitanju oprosta, obrazovanja i razvitka zemlje. ${ }^{42}$ Tako je pobuna okončana bez jasna ishoda, a popločan je put za novi ustanak u proljeće sljedeće godine.

\section{Otpor uoči albanske neovisnosti}

Ustanak 1912. započeo je početkom godine i proširio se na sve albanske teritorije na Balkanu.

U kontekstu tih tenzija albanski nacionalisti sastali su se u Istanbulu 12 . siječnja i odlučili poduprijeti ustanak i lobirati za albansko pitanje u Europi. ${ }^{43}$ Ismail Qemal odlazi u Europu, Hasan Prishtina vraća se na Kosovo ${ }^{44}$, a Syrja Bey u Vloru. Ustanak je započeo na sjevernim albanskim teritorijima na Kosovu, a proširio se ponovno na sve četiri albanske pokrajine (vilajeta) te $u$

38 AAPA, Findbuch, A 9845 (Trieste, den 18 Juni 1911).

39 AAPA, Findbuch, A 9218 (Wien, den 9 Juni 1911).

40 AAPA, Findbuch, Wienner Fremden Blatt, 8. 6. 1911.

${ }^{41}$ GODIN, Aus dem neuen Albanien, 122.

${ }^{42}$ FRASHËRI, Shpallja e pavarësisë së Shqipërisë, 59.

${ }^{43}$ GASHI, Kryengritja e përgjithshme shqiptare e vitit 1912, Kontributi i Kosovës, 116.

${ }^{44}$ FRASHERI, Shpallja e pavarsisë së Shqipërisë, 66. 
Skadar i Bitolu (Manastir). Albanci su opet uputili memorandum s „Crvenom knjigom” kao i 1911. godine. No sada su zahtjevi upućeni Osmanskom Carstvu bili jasniji. Njemački veleposlanik u Carigradu izvijestio je Berlin: „Ozbiljnija nego u Makedoniji situacija je u Albaniji. Tu situacija nema nikakve veze $s$ ratom, nego je posljedica turskih gluposti. Jakobinizam koji je rasprostranjen među turskom upravom pokušao je u Albaniji izostaviti, izjednačiti i potlačiti stanovništvo, što je dovelo do toga da zemlja više nije u stanju pronaći mir. Može se reći da albanski zahtjevi nisu pretjerani, traže bolju infrastrukturu u svojoj zemlji, latinična slova za svoj alfabet i vraćanje starih povlastica vezanih uz poreze i vojsku, koju žele služiti na svojim teritorijima... Vjerujem da je ove godine, uslijed situacije u Albaniji, opasnost od zapaljenja na Balkanu veća nego ikad prije." 45

Izvješća o pobuni u povojima dolazila su i iz njemačkoga konzulata u Trstu, odakle je priopćeno da oružje iz Italije odlazi u Albaniju i da saznanja od Albanaca u Trstu govore o pripremama za ustanak. ${ }^{46}$

Suočeno s tom opasnošću, Osmansko Carstvo odlučilo je već u veljači 1912. da se u Albaniju pošalje ministar unutarnjih poslova Adil Bey, dajući mu ovlaštenje i novac da riješi problem $s$ Albancima općenito ${ }^{47} \mathrm{i}$ da pokaže spremnost vlade za postizanje mira. ${ }^{48}$

Prema izvješću njemačkoga konzulata u Trstu, zbog te je nesređene situacije već u ožujku Osmansko Carstvo počelo premještati postrojbe iz Azije na Kosovo i u Skopje. ${ }^{49}$

Travanjski izbori dodatno su zakomplicirali situaciju kada su u Debru uhićeni albanski plemenski vođe koji su nastojali spriječiti izbornu prevaru. U svibnju se pobuna proširila dalje do Mirdite i Peći. ${ }^{50}$

Iz izvješća njemačkih diplomata u glavnim gradovima drugih velesila, poput Beča, Londona, Sankt Peterburga i Rima, vidimo da je situacija u Albaniji bila u središtu njihove pozornosti. U jednom izvješću iz Rima njemački veleposlanik priopćava da je o albanskoj situaciji razgovarao $s$ talijanskim ministrom vanjskih poslova San Giulianom. ${ }^{51}$

Međutim, albanski pokret bio je podijeljen u tri skupine. Prema njemačkoj dokumentaciji, prva je skupina zahtijevala izvjesnu autonomiju za Albaniju, druga je samo bila protiv turskoga apsolutizma, a treća je htjela povratak na stari režim sultana Abdula Hamida. Ipak, albanski vođe sastali su se 21. - 25. svibnja u Juniku i sastavili memorandum sa 12 točaka, po uzoru na onaj iz 1911., koji su zatim uputili Osmanskom Carstvu, ali i ostalim velesilama. ${ }^{52}$

${ }^{45}$ AAPA, Findbuch, A 631 (Konstanitopel, den 7 Januar 1912).

46 AAPA, Findbuch, A 685 (Trieste, den 9 Januar 1912).

47 AAPA, Findbuch, Nr. 18 (Therapia, den 25 Januar 1912).

${ }^{48}$ AAPA, Findbuch, Nr. 30 (Konstantinopel, den 6 Februar 1912).

${ }^{49}$ AAPA, Findbuch, A 6161 (Salonik, den 1 April 1912).

50 AAPA, Findbuch, A 1954 (Pera, den 9 Mai 1912).

${ }^{51}$ AAPA, Findbuch, A 8733 (Rom, den 15 Mai 1912).

${ }_{52}$ GASHI, Kryengritja e përgjithshme shqiptare e vitit 1912, Kontributi i Kosovës, 119. 
Tijekom lipnja bilo je sporadičnih borbi diljem Kosova, u Skadru i mnogim drugim mjestima. Stožerni časnici i turski vojnici odlazili su na mjesta pobune, pružajući pojačanje i povećavajući pritisak. ${ }^{53}$

U srpnju nije bilo drugoga rješenja i vlada je pala, a 23. srpnja sultan je imenovao Tefika Muhtar-pašu ${ }^{54}$ novim velikim vezirom. On je u svoju vladu imenovao i nekoliko albanskih ministara. Prema njemačkim diplomatima, Muhtar-paša je već dugo pregovarao s Albancima o novom režimu koji je trebao nastupiti u Albaniji i koji bi, među ostalim, Albancima omogućio da nose oružje, ali bi uspostavio i neku vrstu teritorijalne obrane, što je značilo de facto autonomiju Albanije, samo ne tim riječima. ${ }^{55}$ Prema njemačkoj dokumentaciji, to bi naravno otvorilo mogućnost daljnjih sukoba na Balkanu imajući u vidu pretenzije Srbije i Bugarske na te teritorije, što je moglo dovesti do novoga sukoba. ${ }^{56}$

U međuvremenu je albanski ustanak napredovao prema jugu. Albanci su 26. srpnja zaposjeli Kačanik i krenuli prema Skopju, koje su zauzeli 12. kolovoza. ${ }^{57}$ Delegacija predvođena Ibrahim-pašom stigla je 1. kolovoza na Kosovo i započela pregovore. Međutim, pobunjenici su uvjetovali pregovore raspuštanjem parlamenta jer se, prema njihovu mišljenju, izborima manipuliralo, prijeteći da će u suprotnom nastaviti prodor do Soluna. ${ }^{58}$ Parlament je raspušten 5. kolovoza, a Albanci su započeli pregovore s vlastima o zahtjevima poznatima kao zahtjevi Hasana Prishtine:

1) službeno priznanje granica Albanije

2) albanska civilna i vojna uprava

3) Albanci trebaju služiti vojni rok u Albaniji

4) sve administrativne službe trebaju biti u Albaniji. ${ }^{59}$

Dakle, osnovni zahtjev bio je priznavanje granica albanskih teritorija, imajući u vidu želje susjednih zemalja, koje su se zapravo natjecale za dio toga kolača nakon pada Osmanskoga Carstva. To je Austriju nagnalo da pokrene inicijativu za zaštitu statusa quo na Balkanu, o čemu se prethodno savjetovala sa svojim njemačkim saveznicima. ${ }^{60}$ Susjedne zemlje bile su zaokupljene uspjehom albanskoga ustanka više nego vlastitim dugogodišnjim nastojanjima da istisnu Osmansko Carstvo iz Europe. Otvoreno su izražavale zabrinutost zbog jačanja albanskoga elementa, koji je sve više mogao zahtijevati bilo što od Osmanskoga Carstva. ${ }^{61}$ Međutim, inicijativu austrijskoga ministra vanjskih

53 AAPA, Findbuch, A 11155 (Constatinopel, den 25 Juni 1912).

54 AAPA, Findbuch, A 12870 (Therapia, den 20 Juli 1912).

55 AAPA, Findbuch, A 12826 (Constantinopel, den 22 Juli 1912).

56 AAPA, Findbuch, A 13146 (Therapia, den 24 Juli 1912).

7 FRASHERI, Shpallja e pavarsisë së Shqipërisë, 72.

5 AAPA, Findbuch, A 13314 (Therapia, den 1 August 1912), A 13415.

9 GASHI, Kryengritja e përgjithshme shqiptare e vitit 1912, Kontributi i Kosovës, 127.

AAPA, Findbuch, Berlin, den 15 August 1912.

${ }^{61}$ AAPA, Findbuch, A 14514 (Athen, den 18 August 1912). 
poslova Leopolda Berchtolda nisu dobro prihvatile ostale velesile, koje su Austriju optužile da iz vlastitih interesa podupire albansko pitanje. Njemački vojni ataše u Carigradu izvijestio je da Austro-Ugarska pretjerano agresivno zagovara albansko pitanje i decentralizaciju Osmanskoga Carstva, nazivajući pritom Austro-Ugarsku "najvećom državom na Balkanu”. ${ }^{62} \mathrm{U}$ isto je vrijeme crnogorski kralj Nikola povukao zanimljiv potez pokušavajući preko pristaša među albanskim plemenskim vođama nagovoriti i druge albanske vođe da potpišu memorandum kojim se tražilo ujedinjenje Albanije i Crne Gore. ${ }^{63}$

Albanci su 19. kolovoza postigli sporazum s pregovaračima Osmanskoga Carstva. Ibrahim-paša i Albanci napustili su Skopje i bojna polja i vratili se svojim domovima. U jednom se njemačkom izvješću kaže: „Albanci su mirno napustili Skopje." ${ }^{64}$

Crnogorske postrojbe zaposjele su 19 . kolovoza Berane, ${ }^{65}$ što je ražestilo Osmansko Carstvo. Međunarodno povjerenstvo kojem je izneseno to pitanje naredilo je Crnoj Gori da napusti Berane.

U tom su razdoblju njemački diplomati izvještavali o tome kako su u albanskim pokrajinama Albanci de facto preuzeli vlast u svoje ruke. U jednom izvješću iz Carigrada stoji sljedeće: „Austrougarski konzulat iz Mitrovice izvješćuje da šesteročlano povjerenstvo vodi grad, organizirali su pravosuđe, upravljaju i donose odluke. Državni službenici imenovani su u razne službe, Isa Boletin najavio je osnivanje povjerenstva valiji u Skopju, uz napomenu da će 'sada narod sam odlučivati o svojoj budućnosti. Od čovjeka iz Mitrovice saznajemo da je Isa Boletin, uz potporu 6-8 tisuća naoružanih muškaraca, od prošloga tjedna vladar toga grada. Pritom dvije divizije u Mitrovici i oko nje ostaju pasivne, ali drže vojnu situaciju pod kontrolom." 66

Ostale su zabilježene neke zanimljive razmjene mišljenja između njemačkih diplomata i Albanaca o Albaniji, kao i razmjene mišljenja njemačkih diplomata, osobito s austrougarskim kolegama. Prema njemačkoj dokumentaciji, Austrijanci su razmatrali davanje Albanije pod protektorat Rumunjskoj i obnovu za Albance zajedničke stare loze Dačana. ${ }^{67}$ No iz njemačke dokumentacije vidi se i da su drugi bili uvjerenja da Albaniju treba dati pod upravu „europskim protestantima”68, koji ne pripadaju nijednoj od religija u Albaniji. U međuvremenu je Srbija, uz potporu Rusije, otvoreno tražila da joj se odobri okupiranje dijelova albanskih teritorija koji bi joj pripali kao ratni trofej. Njemački veleposlanik poručio je tijekom razgovora s otpravnikom poslova Srbije u Rimu da „ovaj cilj Srbije nije u skladu s interesima velesila. Srbijanski diplomat odgovorio mu je da mu je to jasno, ali ako Srbija okupira

62 AAPA, Findbuch, Therapia, den 8 September 1912.

63 AAPA, Findbuch, A 14194 (Cetinje, den 15 August 1912).

64 AAPA, Findbuch, A 14527 (Therapia, den 21 August 1912).

65 AAPA, Findbuch, Konnstattinopel, den 19 August 1912.

66 AAPA, Findbuch, Therapia, den 3 September 1912.

67 AAPA, Findbuch, A 19892 (Budapest, den 9 November 1912).

68 AAPA, Findbuch, A 9859 (Kopenhagen, den 10 November 1912). 
Albaniju, tko ju može spriječiti? Rat ih je doveo pred još jedan 'svršen čin', pa čak i kada bi to stvorilo izvjesne komplikacije, Srbija bi još uvijek mogla nametnuti svoju volju... Nije to izričito spomenuo, ali je bilo jasno da aludira na potporu Rusije nastojanjima Srbije". ${ }^{69}$

Zaokupljeni vlastitim poslovima, Albanci su izgubili iz vida okolne zemlje i njihove ratne pripreme protiv Osmanskoga Carstva, što je podrazumijevalo brojne sporazume, uključujući i tajne sporazume o podjeli teritorija Osmanskoga Carstva u Europi. S iznimkom Makedonije, koja je bila zabranjeno voće među novim saveznicima, Albanija prema tim planovima nije uopće postojala. Sjeverni dio pripao bi Srbiji i Crnoj Gori, istočni Bugarskoj i Grčkoj, a južni Grčkoj. ${ }^{70}$

Time su izostavljeni zahtjevi velesila Trojnoga saveza, Italije i Austrije. Italija je željela Vloru i zapadnu obalu Albanije, čime bi postigla kontrolu nad ulazom u Jadransko more, a Austrija je željela Skadar, ${ }^{71}$ također da bi imala pristup Jadranu preko Bosne i Hercegovine.

To je vjerojatno spasilo Albaniju i pomoglo joj na njezinu državotvornom putu.

Prvi balkanski rat počeo je 8. listopada 1912., kada je Crna Gora objavila rat Osmanskom Carstvu, a za njom i Srbija, Bugarska i Grčka. Nedugo nakon toga Srbi su ušli na albanske teritorije. Takav razvoj situacije zabrinuo je AustroUgarsku i doveo do prvih raskola u Trojnom savezu između Njemačke, AustroUgarske i Italije. Italija je namjeravala zaposjesti Vloru, a podržavala je i težnje Srbije da dobije izlaz na Jadran u Draču. ${ }^{72}$ Začudo, Albanci se nisu odupirali toj okupaciji ${ }^{73}$ iako su Srbi za sobom ostavili spaljenu zemlju. To je dovelo do dugotrajnih neprijateljstava između tih dviju etničkih skupina. Srpske zločine počinjene nad civilnim albanskim stanovništvom dokumentirao je u jednoj brošuri austrijski istraživač Leo Freundlich. ${ }^{74}$ I međunarodna komisija Zaklade Carnegie prijavila je 1914. slučajeve ubojstva desetaka tisuća albanskih civila, nasilnoga raseljavanja, asimilacije i drugih genocidnih akata počinjenih širom Albanije tijekom balkanskih ratova. U takvoj situaciji Albanci su, potpuno dezorijentirani, sazvali skup u Vlori na kojem su proglasili neovisnost Albanije. Izvornik telegrama Privremene vlade Albanije upućen velikim silama čuva

\footnotetext{
69 AAPA, Findbuch, A 19979 (Rom, den 9 November 1912).

70 AAPA, Findbuch, A 20979 (Wien, den 17 November 1912).

71 Isto.

72 AAPA, Findbuch, Wien, den 18 November 1912.

${ }^{73}$ GODIN, Aus dem neuen Albanien, 12. - Bilo je više razloga zašto se Albanci nisu odupirali toj okupaciji. Prema albanskoj historiografiji, dva glavna bila su: 1) sabotiranje osmanskih generala (mladoturaka) na granicama s Crnom Gorom i Srbijom, ostavljajući lokalne Albance usamljene i bez ozbiljnoga naoružanja da vode sporadične i neuspješne borbe u graničnim predjelima; 2) Albanci su se tijekom trogodišnjih pobuna (1910. - 1912.) iscrpili u neprestanim sukobima s osmanskom vojskom i pretežno ostali bez naoružanja kao posljedica osmanske politike razoružavanja Albanaca. Usp. RIZAJ, Shqipëria e Sipërme, 254-281.

74 FREUNDLICH, Die Albanische Golgatha.
} 
se $\mathrm{u}$ berlinskom arhivu. ${ }^{75}$ Međutim, njihovi teritoriji bili su pod okupacijom Balkanskoga saveza - Srbije, Crne Gore, Bugarske i Grčke - s iznimkom malih žarišta otpora poput onoga u Skadru, a oni su od velesila tražili priznanje svoje države. U zbrci koja je stvorena na Balkanu njihova država nije imala ni definirani teritorij, a kamoli granice.

Čak je njemački car Wilhelm II. naredio svojem kancelaru da, u suradnji sa saveznicama Austro-Ugarskom i Italijom, prizna neovisnost Albanije. Srbi su trebali napustiti albanske teritorije jer to više nisu bili turski teritoriji. ${ }^{76}$ To nije znatno razjasnilo situaciju na terenu. Austro-Ugarska se u Ateni također pobunila protiv okupacije otoka Sazana kod Vlore, ali su Grci kategorički zanemarili te prosvjede, a zapravo su i Vloru držali pod opsadom. ${ }^{77}$

U čitavoj toj zbrci Rusi su iznijeli novi prijedlog: pristat će na autonomiju Albanije uz uvjet da ona ostane osmanski protektorat. To je bio prilično neobičan potez i prijedlog, kojem se njemačko Ministarstvo vanjskih poslova nije protivilo, ali je željelo čuti mišljenje svojih saveznika iz Trojnoga saveza, Austro-Ugarske i Italije. ${ }^{78}$ Poslije je Rusija odustala od te ideje i složila se $s$ prijedlogom sazivanja međunarodne konferencije o tom pitanju. Imajući u vidu složenost situacije koja je nastala na terenu, velesile su odlučile sazvati međunarodnu konferenciju o budućnosti Albanije. Vođene su teške rasprave o tome gdje će se konferencija održati i tko će ju organizirati. Na kraju se većina složila da se treba održati u Londonu, pa je konferencijom koja je počela u prosincu 1912. predsjedao britanski ministar vanjskih poslova Lord Edward Grey. Njemačka je bila jako zainteresirana za konferenciju zbog opasnosti od prerastanja sukoba u europski rat. I unutar Trojnoga saveza postojala su nesuglasja o Balkanu, koja je na konferenciji predstavio briljantni njemački diplomat Karl Max Lichnowsky. On je poslije objavio knjižicu o konferenciji pod naslovom My Mission to London 1912-1914 [Moja misija u Londonu 1912.-1914.], u kojoj je posebno poglavlje posvećeno Albaniji i albanskim granicama, kao i njemačkom stajalištu o tome, što potvrđuje interes Njemačke za to pitanje.

U svojoj publikaciji o Albaniji kaže:

„Albansko pitanje: Prvi balkanski rat doveo je do pada Turske, a time i poraza naše politike koja se već nekoliko godina ravnala prema Turskoj. Budući da Turskoj u Europi više nije bilo spasa, postojala su dva načina na koja smo se mogli ophoditi prema njezinu nasljeđu: mogli smo proglasiti potpunu nezainteresiranost za povlačenje granica i rješavanje toga pitanja prepustiti balkanskim silama ili podržati naše 'saveznike' i nastaviti politiku Trojnoga saveza na Bliskom istoku, odričući se time naše uloge posrednika. Od samoga početka zalagao sam se za ovo prvo, ali je Ministarstvo vanjskih poslova bilo izričito sklono potonjem rješenju.

75 AAPA, Findbuch, A 21218 (29 November 1912).

76 AAPA, Findbuch, A 21429 (Donausschingen, den 30 November 1912).

77 AAPA, Findbuch, A 29803 (Athen, den 5 Dezember 1912).

78 AAPA, Findbuch, A 22716 (Berlin, den 17 Dezember 1912). 
Ključno je bilo albansko pitanje. Naši saveznici težili su uspostavljanju neovisne albanske države jer Austrijanci nisu željeli da Srbi ostvare pristup Jadranu, a Talijani nisu željeli da se Grci domognu Valone, pa čak ni da prodru sjeverno od Krfa. S druge strane Rusija je, kako znamo, podupirala težnje Srbije, a Francuska Grčke. Moj je savjet bio da ovo pitanje riješimo u okviru Saveza te da pritom ne podržimo ni austrijske ni talijanske zahtjeve. Bez naše pomoći ne bi bilo moguće uspostaviti neovisnu Albaniju, koja, po svemu sudeći, nije imala izgleda za opstanak..."

$\mathrm{U}$ isto je vrijeme njemački tisak svakodnevno izvještavao o događajima na terenu, ali i s konferencije u Londonu. Njemačka javnost bila je vrlo dobro upoznata sa situacijom u Albaniji.

Njemačka se u vrijeme uspostavljanja granica Albanije uključila u taj proces, a poslije je nastavila iskazivati svoj interes za Albaniju. Godine 1914. u Tirani je otvorila svoje prvo diplomatsko predstavništvo u Albaniji.

\section{Zaključak}

U albanskoj historiografiji općenito se iznosi da je Njemačka imala prilično nedefinirana stajališta, pa čak i da nije bila naklonjena Albaniji i njezinoj neovisnosti. Ta ideja potekla je od povjesničara iz razdoblja komunizma, a pripisivali su ju kancelaru Ottu von Bismarcku, koji je vodio Berlinski kongres 1878. i koji je, prema navodima tih povjesničara, o Albaniji govorio samo kao o zemljopisnom području. Međutim, u ovom radu pokazuje se da je Njemačka iskazivala interes za događaje u Albaniji i općenito na Balkanu. Kako je rekao Lichnowsky, „bez pomoći Njemačke ne bi bilo moguće uspostaviti neovisnu Albaniju”. Njemačka je preko svojih diplomatskih predstavnika pomno pratila albansko pitanje. Velesile su također sudjelovale na konferenciji veleposlanika u Londonu, gdje se odlučivalo o budućoj državi Albaniji. Nema sumnje da je u većini politika o Balkanu, a ne samo o Albaniji, Njemačka pratila svoju saveznicu Austro-Ugarsku. Međutim, Njemačka se istovremeno zanimala za to pitanje prije svega da bi zaštitila vlastite interese, imajući u vidu, među ostalim, budući gospodarski razvitak regije koji bi Njemačkoj mogao biti od interesa.

\section{Objavljeni izvori}

AAPA, Findbuch: Auswaertiges Amt, Politisches Archiv Findbuch, Berlin, Auswärtiges Amt 1867-1920, Oxford, Teil I und II, 1959.

Sammlung der Diplomatischen Akten des Auswaertigen Amtes, Im Auftrag des Auswaertigen Amtes, Berlin, Die Grosse Politik der Europaeischen Kabinette 1871-1914, Band 32, 33, Berlin 1922 - 1927.

Report of the International Commission to Inquire into the Causes and Conduct of the Balkan Wars, Carnegie Endowment for International Peace,

79 LICHNOWSKY, My Mission to London, 5-6. 
Division of Intercourse and Education, Publication Nr. 4, Published by the Endowment Washington, D.C., 1914.

\section{Literatura}

BARTEL, Peter. Albanien: Vom Mittelalter bis zur Gegenwart. Regensburg: Friedrich Pustel, 1995.

DEUSCH, Engelbert. Das k.(u.)k. Kultursprotektorat im albanischen Siedlungsgebiet. Wien: Boehlau Verlag, 2013.

FRASHËRI, Kristo. Shpallja e pavarësisë së Shqipërisë. Tiranë: Kristalina$\mathrm{KH}, 2008$.

FREUNDLICH, Leo. Die Albanische Golgatha. Wien: J. Roller, 1913.

GASHI, Ibrahim. Kryengritja e përgjithshme shqiptare e vitit 1912, ngjarje që i parapriu shpalljes së pavarësisë së Shqipërisë. U: Roli i Kosovës në krijimin e shtetit shqiptar. Tiranë: Konica Color, 2013.

GODIN, Marie Amelie, Freiien von. Aus dem neuen Albanien. Politische und kulturhistorische Skizzen. Wien: J. Roller, 1914.

GREY, Viscount of Fallodon, K. G. Twenty-Five Years, 1892-1916. New York: Frederick A. Stokes Company, 1925.

Historia e Shqipërisë, sv. II i III. Tiranë: Akademia e Shkencave e RPS të Shqipërisë, Instituti i Historisë, Tiranë, 1984.

IVETIC, Egidio. Luftrat Ballkanike. Tiranë: Dituria, 2008.

LICHNOWSKY, Prince Karl Max. My Mission to London 1912-1914. London: George H. Doran Company, 1918.

PUTO, Arben. Çështja Shqiptare në Aktet Ndërkombëtare të Periudhë së Imperializmit, sv. 1 i 2. Tiranë: Akademia e Shkencave të Shqipërisë, 1984.

PUTO, Arben. Pavarsia Shqiptare dhe Diplomacia e Fuqive te Medha 19121914. Tiranë: Toena, 2012.

RIZAJ, Gazmend. Shqipëria e sipërme 1800-1913. Prishtinë: Instituti Albanologjik, 2011. 


\section{SUMMARY}

\section{The Independence of Albania in 1912 as Documented in German Diplomatic Archives}

The events preceding the independence of Albania are documented in detail in German diplomatic archives. German diplomats from the region, in Istanbul, Athens, Sofia, Thessaloniki, Skopje, and Cetinje as well as in the major powers' capitals - London, Rome, St Petersburg, and Vienna - reported to Berlin on the events in the European part of the Ottoman Empire. The goal of this paper is to study the mentioned documents and make them available to the broader public and younger generations of historians. The bibliography of the German Foreign Ministry, Auswaertiges Amt, Politisches Archiv Findbuch, Auswaertiges Amt 1867 - 1920 Oxford, Teil I und II, 1956, catalogues all available documents on Albania under Ottoman rule till 1914 because the German embassy in Istanbul was responsible for Albania at that time. In 1914, Germany opened its first embassy in Tirana, and from then on documents for Albania were catalogued separately. The archived documents show that Germany was very interested in the events in Albania and actively supported Albanian independence, i.e. the establishment of an Albanian state.

Key words: Albania; Ottoman Empire; Balkans; resistance; Young Turks; independence; German diplomatic documentation 